\title{
Carbon Nanotubes (CNTs): A Potential Nanomaterial for Water Purification
}

\author{
Bharti Arora ${ }^{1, *}$ and Pankaj Attri ${ }^{2, *}$ (D \\ 1 Department of Applied Sciences, The NorthCap University, Sector-23-A, Gurugram, Haryana 122017, India \\ 2 Center of Plasma Nano-Interface Engineering, Kyushu University, Fukuoka 819-0395, Japan \\ * Correspondence: bhartiarora@ncuindia.edu (B.A.); chem.pankaj@gmail.com (P.A.)
}

Received: 23 July 2020; Accepted: 3 September 2020; Published: 10 September 2020

\begin{abstract}
Nanomaterials such as carbon nanotubes (CNTs) have been used as an excellent material for catalysis, separation, adsorption and disinfection processes. CNTs have grabbed the attention of the scientific community and they have the potential to adsorb most of the organic compounds from water. Unlike, reverse osmosis (RO), nanofiltration (NF) and ultrafiltration (UF) membranes aligned CNT membranes can act as high-flow desalination membranes. CNTs provide a relatively safer electrode solution for biosensors. The article is of the utmost importance for the scientists and technologists working in water purification technologies to eliminate the water crisis in the future. This review summarizes about the application of CNTs in water purification.
\end{abstract}

Keywords: CNTs; water purification; adsorption; desalination; catalysis; MFC

\section{Introduction}

Recently, the evolution of nanotechnology has been the one of the fascinating topics among the scientific community for conducting interdisciplinary research [1]. For the first time in 1959, Richard Feynman introduced the term "nanotechnology" [2]. Nanotechnology is described as the study of atomic or molecular aggregates of size ranging from 1 to $100 \mathrm{~nm}$, commonly known as nanoparticles (NPs). NPs also known as ultrafine particles comprising of bulk materials with modified physicochemical properties by varying the size, chemical composition or shape of the particles. They can be of both organic and inorganic nature and are less stable or more reactive. NPs include both nanoparticles. Fullerenes, carbon nanoparticles, dendrimers and liposomes are the common organic nanoparticles. A brief about organic and inorganic nanoparticles is as depicted in Figure 1 [3]

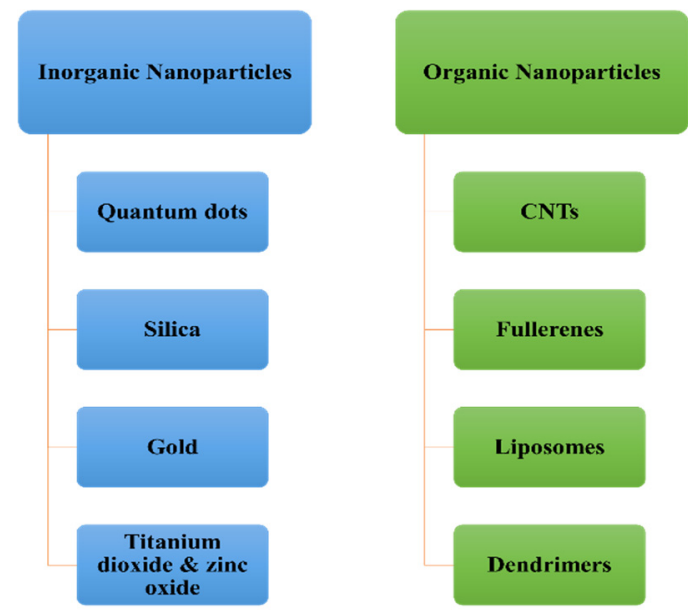

Figure 1. Types of nanoparticles. 
The elevated levels of global warming have led to variation in the properties of natural systems leading to less availability of fresh water in today's time. Although, it seems difficult to eliminate the effect of climatic changes, including global warming and problems arising due to water pollution problems, but the need of effective and low-cost water purification technology has already highlighted the clean water crisis across the globe [4-8]. This water crisis is extremely serious and has been a hindrance in the path of economic growth and social progress [9]. Clean water is an important requirement for human health. Conventional water treatment processes, such as ozone, UV, chlorination and reverse osmosis (R.O.) are very harmful to health and demand a high maintenance cost [10]. Traditional water treatment techniques, including filtration, distillation, coagulation-flocculation, biosand and reverse osmosis fail to remove all heavy metal ions from the water sample.

Nanotechnology seems to provide a promising application in the field of water treatment and remediation wherein various nanomaterials can be exploited to purify water through different mechanisms [11,12]. Some of these are as follows; removal and inactivation of pathogens, adsorption of and various hazardous water contaminants including heavy metals and the transformation of hazardous materials into less hazardous compounds. In order to explore the potential of nanoparticles for water treatment applications, they have been synthesized in different shapes, functionalized with active components and transformed in composites. Nanostructured catalytic membranes have proven to be of great importance in water treatment applications [13]. In this review article, we have tried to throw light on the popular nanomaterials, carbon nanotubes (CNTs) and its application in water purification.

The potential applications of CNT in water purification are critically reviewed in this article. The review summarizes about the latest research studies on CNT to eliminate the water crisis in the future. In this review, we have explained how CNT based membranes are the most reliable solution for water purification problems in addition to their adsorption and sensing and desalination applications. Additionally, we have also mentioned about the toxic effects and challenges involved in the usage of CNTs for water purification, which will pave the way for scientists for future research problems.

\section{Carbon Nanotube Based Water Purification Technology}

Since their discovery, the CNTs have been the center of nanotechnology research because of its remarkable physicochemical properties. These are safe to be used for water treatment applications [14]. Carbon nanotubes (CNTs) are cylindrical macromolecules where the carbon atoms are arranged in the form of a hexagonal lattice in the partitions of the tubes that are capped at the ends with the aid of half of a fullerene-like structure [15]. These are basically classified based on the hybridization of the carbon atom in the CNT layers. Therefore, CNTs can be as single-walled carbon nanotubes (SWCNTs) and multiwalled carbon nanotubes (MWCNTs). The SWCNTs are usually close to $1 \mathrm{~nm}$ in diameter and are several thousand times longer in length. The rolling of a single layer of graphite (called a graphene layer) into a seamless cylinder (long wrapped graphene sheets) may form single-walled carbon nanotubes (SWCNTs). Multiwalled carbon nanotubes (MWCNTs) can be viewed as a series of compressed SWCNTs with different diameters (consisting of several layers of graphite rolled in on it to create a tube shape. Although SWCNTs have diameters of between 0.3 and $3 \mathrm{~nm}$, the MWCNTs can achieve diameters up to $100 \mathrm{~nm}$ [16]. The application of CNTs for different water purification processes are as seen shown in Figure 2 [17].

\subsection{CNTs for Adsorption}

Adsorption refers to a surface phenomenon where the toxic pollutant (sorbate) adsorbs over the surface of a sorbent as an outcome of the force of attraction between them. It arises by external intraparticle/film mass transfer, internal particle pore diffusion and adsorbent sorption and desorption. Apart from the different materials being available as adsorbents including zeolites and resins, activated carbons (ACs) are widely used forms of adsorbents for water treatment due to various advantages: removal of the broad spectrum, pollutant strength, chemical inertia and thermal stability. Nevertheless, 
the use of ACs in water treatment often lacks in certain parameters, including poor adsorption kinetics and regeneration issues. Activated carbon fibers (ACFs) have emerged as the second generation of carbonaceous adsorbents, to address these problems. The openings in ACFs open directly over the carbon matrix area that lessens the distance of contaminants from adsorption sites to diffusion. When compared to ACs, this leads to more adsorption kinetics in ACFs. CNTs having with one dimensional structure seem to be identical to miniaturized ACFs, where all adsorption loci are located on the surface of the inside and outside layer of CNTs. CNTs may take a step ahead forming a convincing third generation of carbonaceous adsorbents because of their layered and hollow architecture and flexible surface chemistry [18]. Burakov et al. contrasted the overall adsorption potential of CNTs for heavy metal with some traditional materials. It has been proposed that plasma-oxidized multiwalled CNTs could be used as adsorbents for some metals instead of chemically oxidized multiwalled CNTs. Plasma oxidized tubes displayed an improved adsorption ability compared with chemically oxidized CNTs, primarily due to the addition of functional groups containing oxygen in the CNT surface. Plasma oxidized CNTs have the tendency to desorb metal ions more easily as shown by the experimental results [19]. Researchers are investigating the feasibility of deploying CNTs for the adsorption of contaminants from the water. For the elimination of toxins in water both MWCNTs [20-22] and SWCNTs [23] have been introduced in recent years. While activated carbon is the most prevalent sorbent demonstrating a specific surface area (SSA) of 500-1000 $\mathrm{m}^{2} \mathrm{~g}^{-1}$ [24], however CNT being a popular adsorbent material because of the unique properties that include; (i) SSA of CNT is high (100-300 $\left.\mathrm{m}^{2} \mathrm{~g}^{-1}\right)$ with a high sorption potential; (ii) a malleable surface charge influences the collection of a particular water pollutant and (iii) an enormous pore size of fibrous material gives more exposure to the surface. Most organic contaminants get adsorbed on the outer layer and internal sites of open-ended CNTs. The accessible surface area and surface functional groups are the main determinants that affect this enhanced adsorption, and these parameters have been the subject of much research.

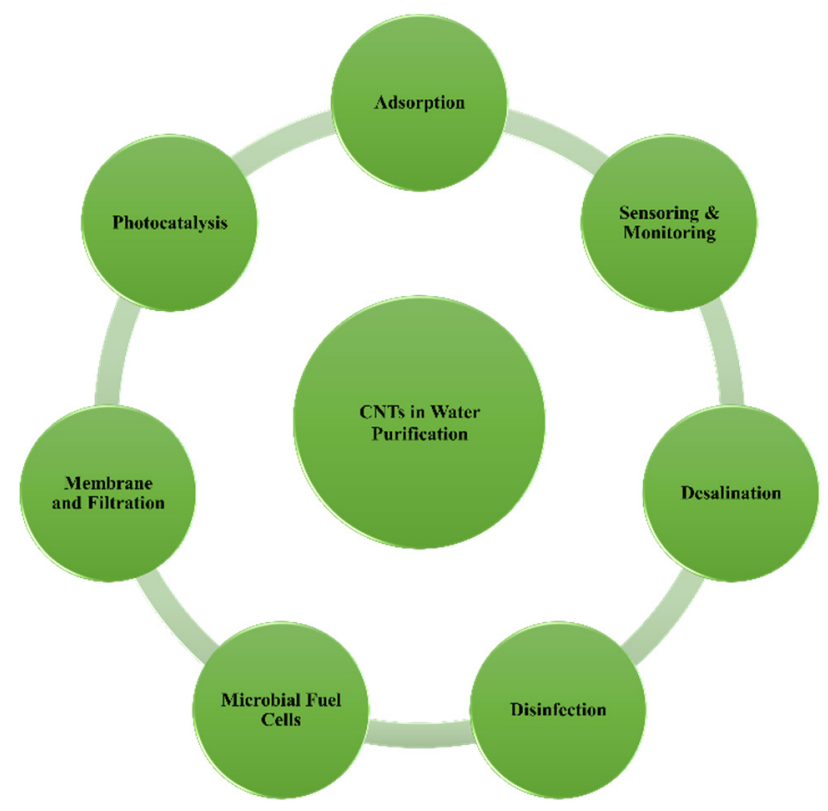

Figure 2. Applications of carbon nanotubes (CNTs) in water purification.

Nonetheless, parameters such as the external surface area, pore density, functionality and purity determine the rate of CNT adsorption [25]. There are four major potential CNT adsorption sites for the adsorption of water contaminants. There are (a) interstitial channels, (b) inner CNT holes, (c) grooves and (d) outer surfaces of the CNT (Figure 3). Interstitial channels serve as a significant trap for small contaminants depending upon the form of the nanotube. For example, because of its aggregation effects, SWCNTs generate more interstitial channels. The aggregation rate declines with growing numbers of 
layers of CNT [26]. The aggregation pattern of CNTs is as follows MWCNTs < DWCNTs) $<$ SWCNTs. The aggregation of CNTs can be beneficial or detrimental for the adsorption [27]. Although, it reduces the total surface area of SWCNTs specifically needed to get pollutants adsorbed in bulk. Not only does it generate interstitial spaces between tubes, which in turn result in the increased size of the pore (chiefly MWCNTs), but the grooves in the peripheral spaces of the CNT bundles also get enlarged. Unlike MWCNTs, the open-ended SWCNTs offer more flexibility in adsorbing multiple adsorbents due to their comparable sizes. SWCNTs having a lower diameter promote adsorption effects in case there is a high possibility of that chemical interactions between the size of the adsorbate and diameter of the nanotube. The outermost surfaces and groove of the CNT bundles serve as beneficial effects for the adsorption of both inorganic and organic contaminants to sit [25].

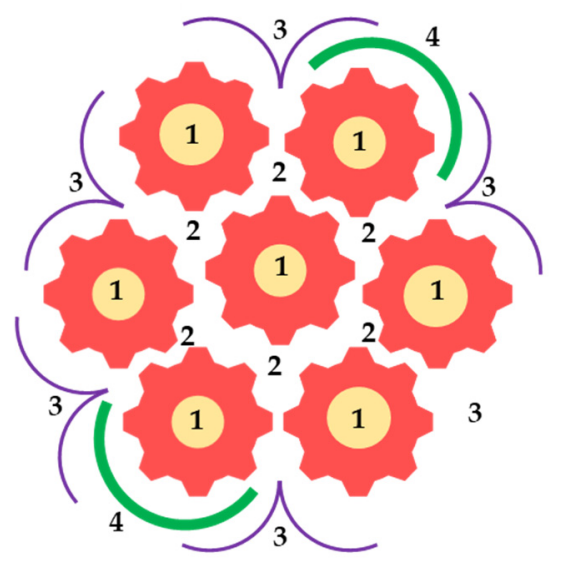

\author{
Interior site (1) \\ Interstitial Site (2) \\ Groove site (3) \\ Exterior site (4)
}

Figure 3. Adsorption sites of CNTs for water pollutants.

CNTs have attracted considerable interest as strong adsorbents for a different variety of organic compounds. These include DDT and its metabolites, dioxin, polynuclear aromatic hydrocarbons (PAHs), PBDEs, chlorophenols and chlorobenzenes, trihalomethane, dyes, phthalate esters, pesticides (thiamethoxam, imidacloprid and acetamiprid) and herbicides such as sulfuron derivatives, and dicamba, atrazine, bisphenol A and nonylphenol [28-30]. It has been revealed that the internal voids of open-ended MWCNTs (2-5 nm) and single-walled (SWCNTs; diameter: 1-2 nm) regulate the amount of sorbed aromatic compounds, for example, 2-phenylphenol $(0.54 \mathrm{~nm})$, phenanthrene $(0.80 \mathrm{~nm})$ and biphenyl $(0.47 \mathrm{~nm})$ [31]. In comparison to SWCNTs, the contribution of internal site pore volumes is relatively more in the case of MWCNTs. The pattern of accumulation decreases the number of walls. Moreover, the accumulation of CNTs follows the following trend: MWCNTs $<$ DWCNTs $<$ SWCNTs. The strong van der Waals forces along the tube length axis in SWCNTs allow them to aggregate, which in turn results in the formation of grooves and interstitial sites. Nevertheless, the SSA of as-grown SWCNTs and MWCNTs is as follows 400-900 $\mathrm{m}^{2} \mathrm{~g}^{-1}$ and 200-400 $\mathrm{m}^{2} \mathrm{~g}^{-1}$, which gets significantly reduced by accumulation [31]. SWCNTs with the same diameter packed into a bundle (homoaggregation) result in the interstitial channel having a uniform diameter. Mismatched diameters in the SWCNT bundle (heteroaggregation) contribute to a greater interstitial channel diameter as compared to homoaggregation [32]. Similarly, aggregated MWCNTs also showed comparable behavior [33]. It has been found that interstitial channels are essential for water contaminants with a diameter of $<1 \mathrm{~nm}$ in the sorption of polycyclic aromatic hydrocarbon (PAH; e.g., tetracene and naphthalene) [26]. The morphology of CNTs, including the nanoscale curvature, is expected to have a major impact on the adsorption of organic contaminants, specifically for those stacked as the $\pi-\pi$ interactive force. A notable difference was observed between the adsorption ability of phenanthrene and tetracene on the tube surface of CNTs due to the nanoscale curvature effect [26].

One limitation that reduces the usage of CNTs as adsorbents for water purification is their high cost as compared to graphite, carbon fiber, carbon black and clay. Functionalization of CNT provides 
a reliable solution to CNT-based water treatment by reducing the cost [34]. By air oxidation or acid oxidation, functional groups like $-\mathrm{C}=\mathrm{O},-\mathrm{COOH}$ and $-\mathrm{OH}$ may be immobilized into $\mathrm{CNT}$ surfaces. The ion exchange, electrostatic interactions, hydrophobic interactions, covalent bonding, $\pi-\pi$ electron binding, hydrogen bonding and mesopore filling are significant factors affecting the interaction between functionalized CNTs and water contaminants. The attachment of functional groups to CNTs increases hydrophilicity and enhances the adsorption capacity for small molecular weight and polar pollutants, such as 1,2-dichlorobenzene [35] and phenols [36]. Sitko et al. [37] widely investigated the role of functionalized CNTs in metal sorption. To sorb the desired pollutants, it is important to understand the CNT with different chemical groups. CNTs are often mixed with other metals or support types to enhance the adsorption, mechanical, optical and electrical properties [38]. The functionalization increases the number of nitrogen, oxygen or other groups on the CNT surface, improves their dispersibility and thus improves the specific surface area [39-41]. For example, Gupta et al. has reported a study using CNTs as a support for magnetic iron oxide [42]. A "composite" adsorbent was designed to remove chromium from the water, combining the adsorption properties of CNTs with the magnetic properties of iron oxide. Apart from having excellent adsorption properties, the "composite" adsorbent can be conveniently isolated from the water by means of an external magnetic field.

The sorption of 1,2-dichlorobenzene (DCB) onto CNTs has been over a broad pH range of 3-10 and that sorption of DCB to CNTs took $40 \mathrm{~min}$ to achieve a maximum sorption of $30.8 \mathrm{mg} / \mathrm{g}$ [35]. In the recent past, new high-surface sorbents (in excess of $189 \mathrm{~m}^{2} / \mathrm{g}$ ) have been prepared consisting of cerium oxide assisted either by aligned carbon nanotubes $\left(\mathrm{CeO}_{2}-\mathrm{ACNTs}\right)$ or carbon nanotubes $\left(\mathrm{CeO}_{2}-\mathrm{CNT}\right)[43,44]$. While the $\mathrm{CeO}_{2}-\mathrm{CNT}$ s were successful As(V) sorbents, the addition of the divalent cations $\mathrm{Ca}(\mathrm{II})$ and $\mathrm{Mg}(\mathrm{II})$ in an increasing concentration from 1 to $10 \mathrm{mg} / \mathrm{L}$ increased the amount of sorbed As(V) (from 10 to $82 \mathrm{mg} / \mathrm{g}$ ) [44].

The activation of CNT using $\mathrm{KOH}$ increases the amount of SSA and mesopore as well as the anchoring of oxy functional groups (OFGs) specifically, the hydroxyl group on the surface of CNTs. It means that significant water contaminants such as $\mathrm{m}$-xylene $(247.83 \mathrm{mg} / \mathrm{g})$, methyl orange (MO; $149 \mathrm{mg} / \mathrm{g}$ ), ethylbenzene (322.05 mg/g), methylene blue (MB; $399 \mathrm{mg} / \mathrm{g}$ ) and toluene $(87.12 \mathrm{mg} / \mathrm{g}$ ) are more likely to be trapped [45]. Not only, CNT functionalization may significantly enhance the sorption of different water contaminants, but also the ability of CNT to host hydrophobic organic water pollutants such as polychlorinated biphenyls, phenanthrene, naphthalene and pyrene, which interact strongly with virgin CNTs through hydrophobic and $\pi-\pi$ interactions, will be reduced. It is important to take great care to operate the material in a regulated manner, so that the hydrophobic CNT skeleton can be preserved and hydrophilic groups for multipollutant adsorption can be immobilized [17].

Surface chemistry is one of the crucial parameters that influence the action of CNT adsorption. The exterior surface of CNTs can not only be used to adsorb organic but inorganic contaminants as well [46]. CNTs have recently been used as strong adsorbents for metal ion adsorption, such as $\mathrm{Ni}^{2+}, \mathrm{Sr}^{2+}, \mathrm{Pb}^{2+}, \mathrm{Zn}^{2+}, \mathrm{Cu}^{2+}, \mathrm{Cd}^{2+}, \mathrm{Co}^{2+}$ and $\mathrm{Cr}^{2+}[47,48]$. Li et al. demonstrated the ability of MWCNTs to adsorb heavy metals such as $\mathrm{Cu}(\mathrm{II}), \mathrm{Pb}(\mathrm{II})$ and $\mathrm{Cd}(\mathrm{II})$ ions. [21]. Kandah et al. revealed that capacities of the MWCNTs to sorb metal-ion are far superior over both the powder and granular activated carbon, being the widely used sorbents used in water purification. Ni(II) ions have also been shown to adsorb onto CNTs [49]. CNT supported cerium oxide $\left(\mathrm{CeO}_{2}\right)$ has been used to fabricate an arsenate sorbent with a high-surface area $\left(189 \mathrm{~m}^{2} \mathrm{~g}^{-1}\right)$ [44]. Functionalized nanosorbents with very small concentrations can target different micropollutants and contaminants. If CNTs are functionalized with $-\mathrm{OH}$ and $-\mathrm{COOH}$, they can adsorb higher concentrations of polar and low molecular weight compounds compared with activated carbon [50]. It was observed that the adsorption of organometallic compounds on pure multiwalled CNTs is greater than for carbon black [51].

Aside from their potential to sorb organic compounds and heavy metals, CNTs offer benefits in water treatment applications as adsorbents for herbicides. Based on a report by [52], indicating that the efficiency of removal of dioxin with CNTs is substantially higher than with activated carbon, and MWCNTs have subsequently been widely used as a preconcentration and chlorophenol separation 
sorbent [53] and varied herbicides, such as sulfonylurea herbicides [54], triazine herbicides [55] as well as DDT and its metabolites [56] from the different water system samples. Another dual functional adsorbent made up of molecularly impressed polymer (MIP) grafted MWCNT (MWCNT-MIP) has been synthesized not only to decompose an organophosphate (OP) pesticide (paraoxone), but also to eliminate the toxic 4-nitrophenol (paraoxone degradation product). Cyano (CN) functionalized CNTs are best suitable for the elimination of phenol-type water pollutants through solid phase extraction (SPE). MWCNT -CN was prone to bind to 2,4-dichlorophenol (DCP), 4-chlorophenol, 1-naphthol and 2 naphthol, respectively, in water at the sea and shore. CNT functionalization with $\mathrm{HNO}_{3}$ and $\mathrm{H}_{2} \mathrm{SO}_{4}$ (1:3) is a common method of wet oxidation for the attaching surface oxide functional groups (OFGs), like carbonyl $(-\mathrm{CQO})$, carboxylate $(-\mathrm{COOH})$ and hydroxyl $(-\mathrm{OH})$. Such functional groups can either be used to adsorb positively charged metal ions including $\mathrm{Cu}$ (II), $\mathrm{Pb}$ (II), $\mathrm{Cd}$ (II) and $\mathrm{Hg}$ (II) from wastewater or to enable covalent attachment functionality for different functional groups such as ethylenediamine and (3-mercaptopropyl) trimethoxysilane (MPTMS) for $-\mathrm{NH}_{2}$ and $-\mathrm{SH}$, respectively [57]. Therefore, it is important to note that in a study, [58] performed a statistical analysis on the cost of the replacement of NaClO-oxidized SWCNTs and MWCNTs, both of which were stated to be potential $\mathrm{Zn}$ (II) sorbents and could be reused through 10 water treatment and regeneration cycles [59,60]. The results showed that these reusable carbonaceous sorbents can provide an economical alternative, ignoring their high unit cost in the current times [58].

In addition to serving as direct adsorbents, CNTs have an amazing scaffold with intrinsic adsorption capacity for the removal of metal oxides. CNTs can be capable of acting as promising support for composite adsorbents because of the tunable surface chemistry and adjustable pore size. CNTs can act as pollutant removal scaffolds. For example, CNT iron oxide for europium adsorption [61], chromium adsorption using ceria nanoparticles [43], adsorption of malachite green using polyaniline [62] and methyl orange adsorption using chitosan [63]. Maggini et al. [64] used poly(vinylpyridine) to coat magnetic CNT to develop a supermolecular adsorbent, demonstrating a unique ability to extract divalent metals from water, and the residual component can be removed by the magnetic field and regenerated by treatment with acid. The special characterstics of CNTs may be used with electrochemical assistance for enhanced adsorption [65].

\subsection{CNTs in the Membrane and Filtration}

Filtration is a physical and mechanical process of separation that allows fluids to flow through the membrane while retaining excessive solutes at the same time. Due to its lower chemical mass, high stability, permeating flux, pollutant retention efficiency, process strength, automated process control and operational robustness, filtration has been the most popular water purification methodologies over the years. Distillation, pervaporation, nanofiltration (NF), ultrafiltration (UF), reverse osmosis (RO), forward osmosis (FO), electrodialysis (ED) and electrodeionization (EDI) are the currently utilized membrane-based filtration methods. The microfiltration (MF) membrane (0.05-1 mm) in the macroporous form contains microorganisms and suspended particles. The mesoporous UF membrane $(0.005-0.5 \mathrm{~mm})$ is typical in majority of the rejected viruses and colloidal substances. Nanoporous NF membrane $(0.0005-0.01 \mathrm{~mm})$, and ED and EDI methods are commonly used to remove inorganic (metals and ions) and organic contaminants. Microporous FO and RO membranes (0.0001-0.001 mm) are water desalination workhorses. Distillation and pervaporation may be used for desalination but are less commonly used in industrial applications in the field. The pitfalls of these filtration processes are fixed solution selectivity, energy intensive operations, regular fouling and low recrudescence. Most filtration membranes have to be cleaned and/or heated with chemicals after several cycles. It has been demonstrated that cleaning and repairing a membrane requires 60 and 30 per cent of the overall pretreatment and desalination costs, respectively. Hence, making the best use of NMs is important to optimize and explore the applications of existing membranes.

In order to enhance the chemical properties specifically hydrophilicity along with the mechanical properties, it was proposed to functionalize CNTs. CNT based smart membranes provide a great 
potential for water purification. However, the scope of composite membranes in water treatment applications can be extended by blending with methodologies [66]. It has been found out that CNTs in combination with membrane filtration technology are capable of removing endocrine disrupting compounds, pharmaceuticals/ personal care products up to 95\% [67].

Types of Nanotube Membranes and Their Fabrication

There are two types of nanotube membranes based on the current fabrication systems, vertically aligned (VA) and mixed matrix (MM) CNT membranes [68]. In the VA-CNT membranes, CNTs are arranged as cylindrical pores that forces the fluid to pass only through the hollow CNT interior or between the CNTs bundles. The VA-CNT membranes can be synthesized between the tubes by aligning perpendicular CNTs with supporting filler material (epoxy, silicon nitride, etc.) [69]. A mixed matrix (MM) CNTs membrane, on the other hand, consists of several layers of polymers or other composite material. Such membranes operate with low energy consumption due to the frictionless capacity of CNT to move water through hydrophobic hollow cavity nanotubes. The membrane is highly sensitive to multiple pollutants and salts, being permeable to antifouling, self-cleaning, reusable and good water. A brief comparison between the vertically aligned and mixed matrix CNT membranes is tabulated in Table 1.

Table 1. A brief comparison between the vertically aligned and mixed matrix CNT membranes.

\begin{tabular}{cc}
\hline Vertically Aligned CNT Membrane & Mixed Matrix CNT Membranes \\
\hline Vertical CNT arrangement & Mixed CNT arrangement \\
Compact CNT network & CNT networks loosely fit \\
Water flux rate is high & Water flux rate is moderately fast \\
Complicated fabrication & Simple fabrication \\
Operating system adjustable & Operating system feasible \\
\hline
\end{tabular}

One promising way of purifying water with CNTs requires VA-CNT sequence membranes. Theoretical and experimental studies demonstrated immense water flow through the VA-CNT membranes, with the purpose of improving the new ultra and nanofiltration substances [70]. Usually, the VA-CNT arrays are synthesized by mounting them on a solid or permeable base and by penetration of a non-porous polymeric material (epoxy, urethane) around the CNTs to ensure the proper positioning [71,72]. Mostly, the work on VA-CNT membranes was associated with desalination, but also the physical removal of organic pollutants [73,74]. Current quality, reliability and long-term performance have restricted the widespread use of VA-CNT membranes, but this method may also be used in combination with other water purification methodologies.

Several techniques have been used to synthesize the MMCNT membranes (Figure 4). The widely employed methods by researchers include phase inversion [75-78], solution mixing [79,80], polymer grafting [81], in-situ polymerization [82-84] and in-situ colloidal precipitation [85], spray-assisted layer-by-layer [86] and interfacial polymerization [87].

Phase inversion can be represented as a process of demixing (liquid-liquid demixing) by transforming a homogeneous polymer solution from a single-phase solution into two solid and liquid phases in a controlled manner [88]. Choi et al. [75] used water as a coagulant phase inversion process to prepare MWCNTs/PSf blend membranes. Interfacial polymerization is a type of step-growth polymerization, which occurs at the interface between two immiscible phases, resulting in a polymer constrained to the interface. Interfacial polymerization [89] has been used for the synthesis of polyamide (PA) RO membranes coupled with CNTs. The aqueous solutions of functionalized CNTs with m-phenylenediamine (MPD) and trimesoyl chloride (TMC) solutions in n-hexane were used for the synthesis of polyamide $\mathrm{RO}$ membranes. 


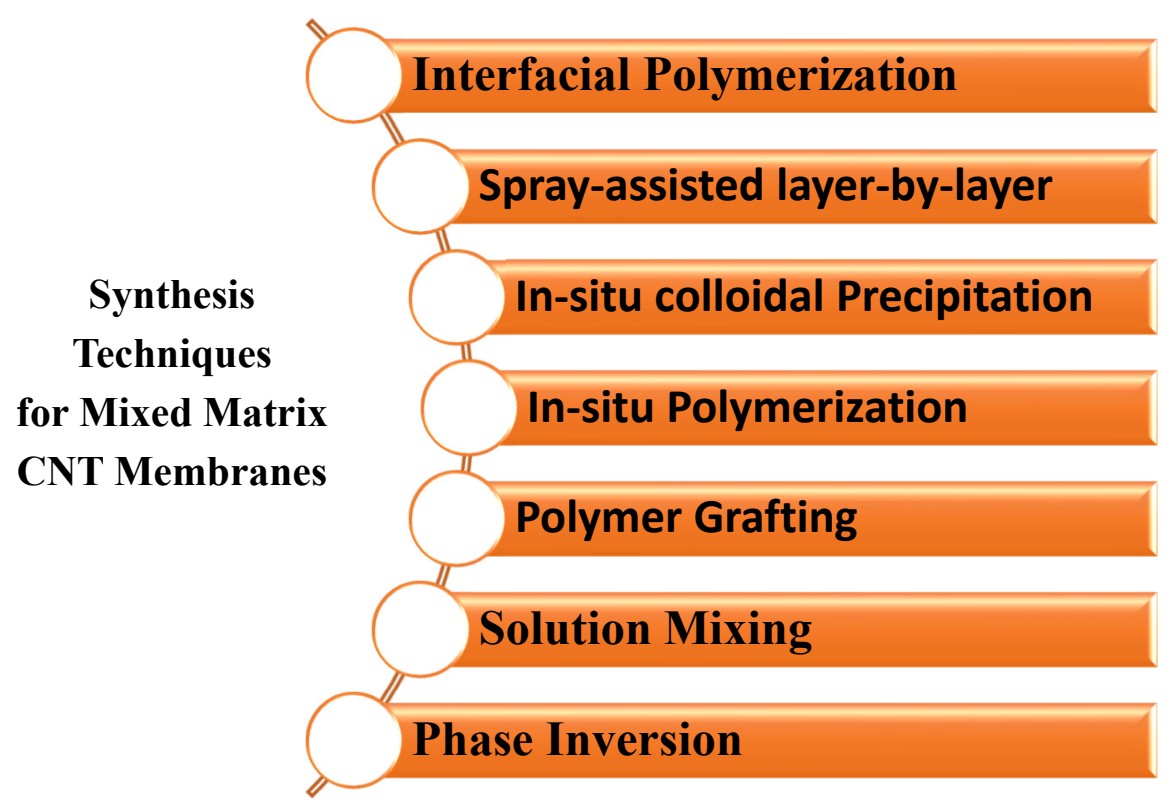

Figure 4. Techniques for the synthesis of mixed matrix (MM) CNT membranes.

Solution blending has been used for synthesizing nanocomposite membranes of PVDF/ poly(styrene-butadiene-styrene)/thiocyanate and silver-modified MWCNTs [80]. Liu et al. [86] used the spray-assisted layer-by-layer technique to prepare the PES/functionalized MWCNT (F-MWCNTs) membrane. Shawky et al. [81] used N, N-dimethylacetamide (DMAc) as a solvent to prepare MWCNT/aromatic PA nanocomposite membranes through a polymer grafting technique. Lee et al. [84] documented the use of MWCNTs/polyaniline (PANI)/PES membranes through in-situ polymerization. The distinctive characteristic of in-situ polymerization is that the raw material contains no reactants. All polymerization occurs in the continuous phase, as in interfacial polymerization, rather than on both sides of the interface between the continuous phase and core material. Ho et al. [85] reported in-situ colloidal precipitation synthesis of the oxidized MWCNTs (OMWCNTs)/graphene oxide (GO)/PVDF membrane.

\subsection{CNTs as the Catalyst}

CNTs are known for providing an exceptional support as a catalyst for a variety of factors: (1) they have a wide specific region, typically $50-1315 \mathrm{~m}^{2} / \mathrm{g}$ [90]. Heterogeneous catalysis for the removal of aqueous contaminants is ideally based on the Langmuir-Hinshelwood process that allows chemicals to be adsorbed before they get depleted on the surface of the catalyst. The growing, unique surface area is useful for the adsorption of the pollutant. Importantly, CNT's actual surface area is relatively lesser than AC's, hence these CNT merits are more relevant; (2) carbonyl and hydroxyl molecules can be used to functionalize CNT through acid treatment and could be further changed for enhancing the adsorption sensitivity to other different chemicals, resulting in "selective degradation" processes such as pollutant degradation rather than benign species and highly toxic contaminants rather than low toxic contaminants; (3) additionally, the consistent permeable framework of CNTs eliminates the limitations of the bulk transfer of reactants from solution to active catalytic sites and (4) strong thermal stability and acidic and basic media resistance and may therefore be used in extreme conditions [18].

\subsubsection{Photocatalysis}

CNTs were used in combination with other semiconductors such as $\mathrm{ZnO}, \mathrm{TiO}_{2}$ and so on as reinforced photocatalytic composite materials [91,92]. This increases the overall photocatalytic efficiency, total surface area, the defects and electrical conductivity [14]. 
Recent studies have illustrated the euphoria of the $\mathrm{CNTs}$ to $\mathrm{TiO}_{2}$ nanoparticles. Increased photocatalytic oxidation activity of $\mathrm{CNT} / \mathrm{TiO}_{2}$ composites to phenol has been evidenced by decreased photoluminescence strength due to reduced recombination load. Due to more individual contact between the surface of the $\mathrm{TiO}_{2}$ nanoparticles and SWCNT, SWCNT are more capable of enhancing the photocatalytic activity of $\mathrm{TiO}_{2}$ compared to MWCNT [93]. Additionally, indium tin oxide (ITO) thin films have been used at the interface between $\mathrm{SWCNTs}$ and $\mathrm{TiO}_{2}$. This helped in decreasing the resistance between the two layers and showed a significant part in improving photo electrochemical behavior [94].

CNT-TiO ${ }_{2}$ composites are found to be efficient in photodegrading aqueous contaminants, including carbamazepine [95], derivatives of benzene [96] and dyes [97]. The $\mathrm{CNT} / \mathrm{TiO}_{2}$ composite repeated photocatalytic operation as revealed by the removal of nitro phenols from real sunlight wastewater [98]. CNT applications often include the use of CNTs as pillars of reduced graphene oxide platelets for rhodamine B (RhB) degradation [99], and the preparation of Au NP@POM-CNT tricomponent hybrid photocatalyst [100]. Despite being capable as effective visible light photosensitizers, Au nanoparticles are inconsiderable of photocatalytic activity because of the rapid rate of the recombination of charges. The excellent electron-conductive capacity of the CNTs has made the Au NP@POM-CNT hybrid an effective visible light catalyst. It was reported that Ag's loading into CNTs clearly increased CNT's photocatalytic activity. The Ag/CNT composite had a photocatalytic degradation action against $\mathrm{RhB}$ [101]. Qu et al. reported that CNTs synthesized from poplar leaves can photocatalytically degrade bisphenol A, and CNT in combination with metal oxide that induced the photocatalytic activity on the CNT surface [102].

\subsubsection{Catalytic Wet Air Oxidation (CWAO)}

Wet air oxidation uses air oxygen to oxidize suspended and dissolved organic matter in water and has been used widely for about 60 years as an efficient tool for handling wastewater. Nevertheless, high operating costs and extreme reaction conditions prohibit its use for industrial wastewater treatment. Additionally, it was observed that the efficiency of oxidation can be improved and can be made cost effective by using catalysts (usually noble metals) in the process of wet air oxidation [18].

Several researchers used CNT in catalytic wet air oxidation to treat biological and toxic wastewater [103-108]. The mesoporous design of CNTs, as opposed to AC, is much preferred for the diffusion of contaminants to the catalyst surface. Additionally, many scientists have used CNTs in combination with catalysts like Pd, Pt, Ru $[104-106,108]$ and so on to improve catalytic performance and reduce costs [18]. Yang et al. [107] revealed about the functionalized phenol MWCNTs in a batch reactor for catalytic wet air oxidation (CWAO). At $160^{\circ} \mathrm{C}$ and $2.0 \mathrm{MPa}$, carboxylic groups $(-\mathrm{COOH})$ on CNTs showed excellent catalytic performance in phenol oxidation $(1000 \mathrm{mg} / \mathrm{L})$. Liquid oxygen has been shown to get adsorbed, which further resulted in dissociation on graphite sheets of MWCNTs and resulted in the dissociation of oxygen atoms (DOA) [109]. Kim et al. [110] summarized the CNTs based CWAO process for the mineralization of primary industrial organic water contaminants.

\subsection{Carbon Nanotube Materials for Antimicrobial and Antibiofouling}

One of the important applications of CNTs in water purification is for the inactivation of bacteria and viruses or nanofiltration to remove these microorganisms from the water. An antifouling capacity to prevent the adhesion of bacteria and the formation of biofilms is another desirable property for advanced water purification materials. Different CNT composite materials have been explored to determine the platforms for water purification neutralization and antifouling [111].

CNTs also exhibit certain intrinsic antimicrobial activity. It has been shown that highly purified SWCNT aggregates resulted in the damage of irrecoverable Escherichia coli K12 membrane through physical interaction with SWCNT leading to bacterial cell death [112]. Membrane disruption eventually contributes to reduced permeability of the membrane. This was further proved by calculating the efflux of cytoplasmic materials into the solution. It was confirmed that the concentrations of plasmid DNA 
and RNA in contact with SWCNTs in solution almost doubled and even increased up to 5 times [112]. Therefore, SWCNTs were proposed as elementary units for antimicrobials. Many researchers have also proposed that the main killing mechanism is the physical interaction of carbon-based nanomaterials with cells [113]. SWCNTs have been demonstrated to have antibacterial activity against Gram-positive and Gram-negative bacteria in their monocultures, in normal microbial river water populations and in wastewater effluent [114].

Due to the nanoscale characteristics of CNTs, this material is a promising means of producing size exclusion membranes, capable of preventing the transportation of certain microorganisms across the membrane. Aggregated CNTs accumulated on a porous polymer membrane can effectively remove bacteria from aqueous solutions, where the concentration of CNT loads also affects the filtration ability of viruses [115]. A special polymer bound, vertically aligned CNTs membrane has been fabricated for bacteria and virus filtration enabling a size exclusion of sub $5 \mathrm{~nm}$ materials [116]. Lee et al. [72] observed that self-supported CNT membranes resisted bacterial adhesion and the same being due to an effect of the nanoscale surface roughness. An epoxy entangled vertically aligned CNT material has exhibited similar antibiofouling properties to microorganisms with physical damage and oxidant stress [117]. By incorporating the natural bactericide nisin into the CNTs, a more direct approach to the manufacture of antibacterial CNT water purification membranes was achieved [118]. The nisin adsorbed CNTs were then sprayed onto a filter membrane of polycarbonate where bacteria would be trapped and then neutralized. It has been seen that Gram-positive bacteria being soft and smooth cells were found to be more susceptible towards an attack by CNTs as compared to Gram-negative bacteria.

\subsection{Desalination}

Since brackish water and seawater sources form approximately $98 \%$ of all Earth's water, collecting a small fraction is anticipated to have a significant effect on water shortage issues. Consequently, desalination of seawater and brackish water through various desalting technologies seems to be the most upfront and promising ways to enhance the water supply by producing more freshwater from seas. The CNT membrane is a single, open ended, hollow structure oriented perpendicularly to the impermeable filler matrices. Aligned CNT membranes can act as high-flow desalination membranes. A catalytic chemical vapor deposition was used to produce a sub-2-nm aligned nanotube membrane and further uncap the nanotubes by laser etching [119]. CNT membranes have already shown strong permeability of water and rejection of salt, making them interesting for desalination.

Unlike reverse osmosis (RO) and nanofiltration (NF) membranes that purify water at diffusion, an ultrafiltration (UF) membrane removes suspended water particles. On the other hand, a CNT membrane not only helps to remove suspended solids and dissolved ions but also is beneficial for gas separation [120]. Unlikely, RO, NF and UF where the elementary units are organic polymers; CNT is a carbon allotrope. Compared to conventional membranes, CNT membranes are often functionalized with other nanoparticles such as $\mathrm{TiO}_{2}, \mathrm{Ag}$ and $\mathrm{Fe}_{3} \mathrm{O}_{4}$, which may have specific physicochemical characteristics [121].

The highest water permeability of CNT bucky paper and retention of sodium ions was observed [122]. Additionally, the CNT interface may be modified by implanting various functionalities such as negative $\left(-\mathrm{COO}^{-}\right.$and sulfonic acids), positive $\left(-\mathrm{NH}_{3}{ }^{+}\right)$and hydrophobic (aromatic) groups by different wet oxidizing agent treatments [123]. The groups can reject a single pollutant and draw molecules of water through the nanotube opening. Ratto et al. [124] have patented a CNT based membrane with ion rejection efficiency of greater than 99\%. This suggests the potential of CNT based membranes for desalination applications. Additionally, Yang et al. have used plasma to modify CNTs and revealed that the capacity to adsorb salt exceeded $400 \%$ by weight. Additionally, the efficiency is twice as compared to activated carbon-based materials for water desalination [125]. Although, nanotube-based membranes have smaller pore sizes, their water permeability has been found out to be relatively much higher than that of conventional polycarbonate membranes. High density vertically aligned CNT membranes were synthesized so that full advantage of the inside pores of CNTs can be 
explored [126]. Gong et al. [127] designed a controllable ion-selective nanopore based on SWCNTs with varying arrangement of carbonyl oxygen atoms inside the nanopores. Such nanopores possess tunable ionic selectivity by varying patterns of carbonyl oxygen atoms, which regulate the hydration arrangement of $\mathrm{Na}^{+}$and $\mathrm{K}^{+}$inside the nanopores Majumder et al. [128] used electrochemical grafting of diazonium salts to modify the tips of CNTs and suggested that the varying voltage can help to tune the separation coefficient of the CNT membranes. Additionally, aligned CNT membranes reject ions efficiently up to $98 \%$ ions on introducing negatively charged moieties through plasma treatment, and the charge exclusion mechanism was used for the exclusion of ions [129].

Son et al. immobilized functionalized CNTs in the porous support layer to develop a novel architecture for increasing the performance of thin-film composite membrane for seawater and brackish water reverse osmosis [130]. With the increase in hydrophilicity and pore characteristics of the support layer, water permeability of the new membranes gets better without affecting the movement of the solvent.

\subsection{CNTs for Sensing and Monitoring}

Using conventional sensor technologies, rapid detection of toxic water contaminants has become a challenging task. Additionally, complex wastewater matrices have urgently increased this adversity. The perspective led to the development of highly sensitive and quick responsive sensors based on CNT due to certain characteristics of CNT such as high adsorbent strength so that water contaminants aggregate on their surface before sensing and trapping, strong electro conductivity, hydrophobicity, high recovery rate and kinetics of the first reaction. Enzymes that are immobilized on CNTs oxidize water contaminants accompanied by the transformation of electrons to detect a high signal. Additionally, the electrical conductance of charged or ionic contaminants adsorbed into CNTs can be calculated as the ratio between analyte concentrations and current fluctuations. An enzyme (tyrosinase)-integrated-CNTepoxy composite electrode (CNTECE-Tyr) was developed by López and Merkoçi [131]. A tyrosinase biosensor is based on a graphite epoxy-composite (GECE-Tyr), which can be used for monitoring phenolic water toxins such as catechol. It was investigated that the CNTEC-Tyr electrode showed excellent electrocatalytic behavior of CNTs over a graphite sheet by exhibiting higher signals.

The use of CNTs as an electrode for biosensors applications is relatively safe. Direct water interaction with the CNT electrode is rarely possible. Nonetheless, some measurements of the risk may be followed. Firstly, for high electroconductivity and mechanical strength 1D CNTs are mostly paired with 2D NMs, specifically with graphene. These macro frameworks have varied physicochemical characteristics and present various environmental risks that need to be carefully evaluated [132]. Additionally, poly (diallyl dimethylammonium chloride) (PDDA)-functionalized CNTs are widely popular for electrochemical biosensor applications. CNTs-PDDA is hazardous as the polymer can influence hemolysis and cell viability [133]. To investigate chemical, inorganic and biological water contaminants, biomolecules such as DNA, proteins and others have been commonly immobilized on CNTs. This biomolecules' preferred immobilization approach is physical adsorption rather than covalent modifications to preserve the integrity of the CNT and the structure of the biomolecule that results in high electrical conductivity. Since biomolecules leached from the system are also harmful to human beings, such a system is not stable and enduring. Consequently, the efficiency of a biosensor and its risk quantifications depend entirely on the strategies taken to yield the end-product. Although the use of carbon nanotube structures in separation technology has been proposed, it remained a challenge to build macroscopic molecules that control geometric shapes, dimensions and density for specific filtration applications [134]. Srivastava et al. fabricated carbon nanotube filters, which helped in the removal of bacterial pathogens (Escherichia coli and Staphylococcus aureus) and Poliovirus sabin 1 from contaminated water. It has been found that such carbon nanotube filters can be reused and can be washed by autoclaving or ultrasonication. It is predicted that the unique characteristics of CNT based filters including a combination of mechanical and thermal stability of nanotubes with 
cost-effective fabrication of the nanotube membranes with the high surface area may compete with commercially available ceramic and polymer-based separation membranes [135]. The fabrication of innovative nanocapillary array (NCA) membranes with scaled down fouling tendency and increased solute retention has also been studied [136].

\subsection{CNT Electrodes as a Microbial Fuel Cell (MFC)}

Microbial fuel cell (MFC) is an environmentally sustainable system for treating wastewater with the use of microorganisms to produce self-supporting electricity. MFC can be characterized as a bio electrochemical cell or system in which current is generated using microorganisms, imitating natural bacterial interaction. The performances of MFCs, which can be determined in terms of chemical oxygen demand and its removal and electricity generation, is dependent on various aspects, including the electrode material, $\mathrm{pH}$, reactor design and microbial species. The device consists of two electrodes-the anode and cathode-divided by a membrane in different compartments. The anodic section can be packed with wastewater, which acts as oxidized nutrients by microbes leading to the production of protons, electrons and carbon dioxide. The outside membrane of cells of bacteria has redox proteins (cytochromes) that serve as an intermediary to pass the electrons to the cathode. Another significant parameter in boosting the power density of MFC is the anode-microbe interaction. Promising anode materials can be CNTs with a high surface-to-volume ratio and high conductivity. Due to the extensive surface area along with a high aspect ratio, CNTs have high electrical conductivity and offer a convincing future for better electrode-microbial interactions. Moreover, the cytotoxicity of CNT limits its application in MFC, which can impact the bacterial growth. CNTs when layered with conductive polymers, like polypyrrole [137] and polyaniline [138], can be used as the anode substrate and are suitable for the expansion of the SSA of the electrode. These further result in the improvement of charge transfer efficiency.

Additionally, surface oxidation could improve CNT biocompatibility. The vertically grown oxidized-MWCNT has been deployed as an anode to fabricate a MFC at the microscale (1.5 $\mu \mathrm{L})$ [139]. CNTs can also be used to assemble electrodes with innovative structures. A uniform coating of CNT on macroscale porous substrates results in a three-dimensional structure [140]. The microbial biofilm interacts strongly with the 3D CNT anode and facilitates the displacement of electrons from exoelectrogens to the electrode surface, thereby significantly reducing the load transfer resistance and improving MFC efficiency [136]. In the MFC cathode, electrons are generally taken up by oxygen, the most dependable acceptor of terminal electrons. Poor reactions under reduced oxygen operating conditions decrease MFC efficiency. Few bacteria may catalyze cathode reactions to the oxygen reduction. CNTs are in great proximity with the redox active center of redox proteins inside these bacteria due to their size and shape, thus facilitating electron transfer along with an enhanced rate of the oxygen reduction reaction [141]. CNT also serve as a desirable support for other electrocatalyst oxygen reduction reactions, such as manganese dioxide [142,143]. We can say that the unique structure of CNTs with good electrical properties makes them exceptional as the future MFC electrodes.

\section{Toxic Potential of CNTs}

Several researchers stated that the respiratory system might be susceptible to CNTs, which could result in serious health issues including bronchitis, lung cancer, emphysema and asthma. Additionally, a few industrial plants seem to be potentially dustier due to the lack of hygiene conditions at the industrial level [144]. The use of pulverized CNTs or composites containing fine CNT particles may present an inhalation exposure. Several laboratory research on inhalation risk have helped in understanding the impact of CNTs on the respiratory tract and to define the exposure limits.

CNTs are known to be carcinogenic and can trigger tumors in the lung. The carcinogenicity of CNTs will, however, diminish if the fiber length is shorter [145]. The detrimental effects of nanotoxicity have been overlooked on vulnerable populations including pregnant women, neonates, aged populations and diseased populations. Research indicates that they suffer more from differences in physiological 
structures and functions, and their responses are also more extreme [146]. The toxicity of CNTs depends primarily on the aggregation state, volume, stiffness, concentration, exposure period and so on. Most parameters are responsible for the toxicity of CNTs such as the manufacturing process, purification and preparation of the tested formulations [145]. These CNTs have a high risk of interacting with specific biomolecules found in the water system that could potentially have harmful effects on the marine ecosystem [121].

One major challenge is the difficulty of designing and developing biocompatible CNTs in this area [147]. Most research on CNT toxicity demonstrated the insoluble nature and toxicity of CNTs in water. Carboxyl, amine and hydroxyl groups may be used in some cases to functionalize CNTs and enhance their solubility in water.

\section{Conclusions}

The researchers claimed that carbon nanotubes (CNTs) are the most promising adsorbents for various environmental applications including water purification. The CNTs are innovative one-dimensional macromolecules with high thermal and chemical stability. CNT based technology may be integrated with the conventional water treatment processes by developing new cost-effective and efficient manufacturing processes.

Several studies have been conducted on CNT supported catalysts focusing on the enhanced catalytic activity by making use of some standard pollutants, such as dyes or phenol. CNTs offer various advantages over conventional techniques for water treatment. They act as an effective adsorbent offering superior adsorption selectivity, larger adsorption capacity, easier regeneration, and shorter equilibrium. Secondly, CNT based filters are excellent in the removal of bacteria and viruses through adsorption and microbe killing. They have great application in the filtration application. Additionally, CNT based polymeric membranes show better water permeability, higher strength and antifouling ability. The fascinating feature is to explore the ability of a CNT based membrane to maintain both high flux and high selectivity for water desalination. Due to the immense adsorption capacity, electrical conductivity and high strength, CNTs provide excellent catalyst support. For example, combining CNT with $\mathrm{TiO}_{2}$ can provide improved visible photoactivity and better charge separation.

Major challenges include the manufacturing cost of CNT and optimization of CNTs in terms of alignment, uniform dispersion, functionalization and tip opening. Since, CNTs exhibit cytotoxicity, risk involved in the leakage of CNT in water treatment devices needs to be properly examined. It is hopeful that the use of CNTs in water purification applications brings a revolution and improves the existing technologies.

Author Contributions: B.A.; writing—original draft preparation, B.A., P.A.; writing—review and editing. All authors have read and agreed to the published version of the manuscript.

Funding: P.A. thankful to JSPS-KAKENHI grant number 20K14454.

Conflicts of Interest: The authors declare no conflict of interest.

\section{References}

1. Baker, S.; Satish, S. Endophytes: Toward a Vision in Synthesis of Nanoparticle for Future Therapeutic Agents. Int. J. Bio-Inorg. Hybrid Nanomater. 2012, 1, 67-77.

2. Feynman, R. There's plenty of room at the bottom. In Feynman and Computation; Taylor \& Francis: Abingdon, UK, 2018; pp. 63-76. ISBN 9780429969003.

3. Yadav, K.K.; Singh, J.K.; Gupta, N.; Kumar, V. A review of nanobioremediation technologies for environmental cleanup: A novel biological approach. J. Mater. Environ. Sci. 2017, 8, 740-757.

4. Garg, S.; Bhatia, R.; Attri, P. Black but gold: Carbon nanomaterials for waste water purification. In Nanomaterials for Water Remediation; De Gruyter: Berlin, Germany, 2020; pp. 42-92.

5. Mishra, A.K. Smart Ceramics: Preparation, Properties, and Applications; CRC Press: Boca Raton, FL, USA, 2018; ISBN 9781351671644. 
6. Arora, B.; Choi, E.H.; Shiratani, M.; Attri, P. Cellulose: A Smart Material for Water Purification. In Smart Materials for Waste Water Applications; John Wiley \& Sons, Inc.: Hoboken, NJ, USA, 2016; pp. 335-346.

7. Attri, P.; Tochikubo, F.; Park, J.H.; Choi, E.H.; Koga, K.; Shiratani, M. Impact of Gamma rays and DBD plasma treatments on wastewater treatment. Sci. Rep. 2018, 8, 2926. [CrossRef]

8. Attri, P.; Yusupov, M.; Park, J.H.; Lingamdinne, L.P.; Koduru, J.R.; Shiratani, M.; Choi, E.H.; Bogaerts, A. Mechanism and comparison of needle-type non-thermal direct and indirect atmospheric pressure plasma jets on the degradation of dyes. Sci. Rep. 2016, 6, 34419. [CrossRef]

9. Das, R.; Ali, M.E.; Hamid, S.B.A.; Ramakrishna, S.; Chowdhury, Z.Z. Carbon nanotube membranes for water purification: A bright future in water desalination. Desalination 2014, 336, 97-109. [CrossRef]

10. Al-Abri, M.; Al-Ghafri, B.; Bora, T.; Dobretsov, S.; Dutta, J.; Castelletto, S.; Rosa, L.; Boretti, A. Chlorination disadvantages and alternative routes for biofouling control in reverse osmosis desalination. NPJ Clean Water 2019, 2, 2. [CrossRef]

11. Lingamdinne, L.P.; Chang, Y.Y.; Yang, J.K.; Singh, J.; Choi, E.H.; Shiratani, M.; Koduru, J.R.; Attri, P. Biogenic reductive preparation of magnetic inverse spinel iron oxide nanoparticles for the adsorption removal of heavy metals. Chem. Eng. J. 2017, 307, 74-84. [CrossRef]

12. Attri, P.; Arora, B.; Bhatia, R.; Venkatesu, P.; Choi, E.H. Plasma Technology: A New Remediation for Water Purification with or without Nanoparticles. In Application of Nanotechnology in Water Research; John Wiley \& Sons, Inc.: Hoboken, NJ, USA, 2014; pp. 63-77, ISBN 9781118939314.

13. Ghasemzadeh, G.; Momenpour, M.; Omidi, F.; Hosseini, M.R.; Ahani, M.; Barzegari, A. Applications of nanomaterials in water treatment and environmental remediation. Front. Environ. Sci. Eng. 2014, 8, 471-482. [CrossRef]

14. Baby, R.; Saifullah, B.; Hussein, M.Z. Carbon Nanomaterials for the Treatment of Heavy Metal-Contaminated Water and Environmental Remediation. Nanoscale Res. Lett. 2019, 14, 341. [CrossRef]

15. Iijima, S. Helical microtubules of graphitic carbon. Nature 1991, 354, 56-58. [CrossRef]

16. Balasubramanian, K.; Burghard, M. Chemically functionalized carbon nanotubes. Small 2005, 1, $180-192$. [CrossRef] [PubMed]

17. Das, R.; Vecitis, C.D.; Schulze, A.; Cao, B.; Ismail, A.F.; Lu, X.; Chen, J.; Ramakrishna, S. Recent advances in nanomaterials for water protection and monitoring. Chem. Soc. Rev. 2017, 46, 6946-7020. [CrossRef] [PubMed]

18. Liu, X.; Wang, M.; Zhang, S.; Pan, B. Application potential of carbon nanotubes in water treatment: A review. J. Environ. Sci. 2013, 25, 1263-1280. [CrossRef]

19. Burakov, A.E.; Galunin, E.V.; Burakova, I.V.; Kucherova, A.E.; Agarwal, S.; Tkachev, A.G.; Gupta, V.K. Adsorption of heavy metals on conventional and nanostructured materials for wastewater treatment purposes: A review. Ecotoxicol. Environ. Saf. 2018, 148, 702-712. [CrossRef] [PubMed]

20. Cho, H.H.; Wepasnick, K.; Smith, B.A.; Bangash, F.K.; Fairbrother, D.H.; Ball, W.P. Sorption of aqueous Zn[II] and $\mathrm{Cd}[\mathrm{II}]$ by multiwall carbon nanotubes: The relative roles of oxygen-containing functional groups and graphenic carbon. Langmuir 2010, 26, 967-981. [CrossRef] [PubMed]

21. Li, Y.H.; Ding, J.; Luan, Z.; Di, Z.; Zhu, Y.; Xu, C.; Wu, D.; Wei, B. Competitive adsorption of Pb2+, Cu2+ and $\mathrm{Cd} 2+$ ions from aqueous solutions by multiwalled carbon nanotubes. Carbon 2003, 41, 2787-2792. [CrossRef]

22. Madrakian, T.; Afkhami, A.; Ahmadi, M.; Bagheri, H. Removal of some cationic dyes from aqueous solutions using magnetic-modified multi-walled carbon nanotubes. J. Hazard. Mater. 2011, 196, 109-114. [CrossRef]

23. Yang, C.M.; Park, J.S.; An, K.H.; Lim, S.C.; Seo, K.; Kim, B.; Park, K.A.; Han, S.; Park, C.Y.; Lee, Y.H. Selective removal of metallic single-walled carbon nanotubes with small diameters by using nitric and sulfuric acids. J. Phys. Chem. B 2005, 109, 19242-19248. [CrossRef]

24. Chowdhury, Z.Z.; Hamid, S.B.A.; Das, R.; Hasan, M.R.; Zain, S.M.; Khalid, K.; Uddin, M.N. Preparation of carbonaceous adsorbents from lignocellulosic biomass and their use in removal of contaminants from aqueous solution. BioResources 2013, 8, 6523-6555. [CrossRef]

25. Das, R.; Abd Hamid, S.B.; Ali, M.E.; Ismail, A.F.; Annuar, M.S.M.; Ramakrishna, S. Multifunctional carbon nanotubes in water treatment: The present, past and future. Desalination 2014, 354, 160-179. [CrossRef]

26. Gotovac, S.; Honda, H.; Hattori, Y.; Takahashi, K.; Kanoh, H.; Kaneko, K. Effect of nanoscale curvature of single-walled carbon nanotubes on adsorption of polycyclic aromatic hydrocarbons. Nano Lett. 2007, 7, 583-587. [CrossRef] [PubMed] 
27. Zhang, S.; Shao, T.; Bekaroglu, S.S.K.; Karanfil, T. The impacts of aggregation and surface chemistry of carbon nanotubes on the adsorption of synthetic organic compounds. Environ. Sci. Technol. 2009, 43, 5719-5725. [CrossRef]

28. Yang, K.; Wang, X.; Zhu, L.; Xing, B. Competitive sorption of pyrene, phenanthrene, and naphthalene on multiwalled carbon nanotubes. Environ. Sci. Technol. 2006, 40, 5804-5810. [CrossRef]

29. Yang, K.; Xing, B. Desorption of polycyclic aromatic hydrocarbons from carbon nanomaterials in water. Environ. Pollut. 2007, 145, 529-537. [CrossRef]

30. Gotovac, S.; Hattori, Y.; Noguchi, D.; Miyamoto, J.I.; Kanamaru, M.; Utsumi, S.; Kanoh, H.; Kaneko, K. Phenanthrene adsorption from solution on single wall carbon nanotubes. J. Phys. Chem. B 2006, 110, 16219-16224. [CrossRef]

31. Bhushan, B. (Ed.) Springer Handbook of Nanotechnology; Springer: Berlin/Heidelberg, Germany, 2004; ISBN 978-3-540-01218-4.

32. Sun, F.; Gao, J.; Zhu, Y.; Chen, G.; Wu, S.; Qin, Y. Adsorption of SO2 by typical carbonaceous material: A comparative study of carbon nanotubes and activated carbons. Adsorption 2013, 19, 959-966. [CrossRef]

33. Yang, Q.H.; Hou, P.X.; Bai, S.; Wang, M.Z.; Cheng, H.M. Adsorption and capillarity of nitrogen in aggregated multi-walled carbon nanotubes. Chem. Phys. Lett. 2001, 345, 18-24. [CrossRef]

34. Ali, S.; Rehman, S.A.U.; Luan, H.Y.; Farid, M.U.; Huang, H. Challenges and opportunities in functional carbon nanotubes for membrane-based water treatment and desalination. Sci. Total Environ. 2019, 646, 1126-1139. [CrossRef]

35. Peng, X.; Li, Y.; Luan, Z.; Di, Z.; Wang, H.; Tian, B.; Jia, Z. Adsorption of 1,2-dichlorobenzene from water to carbon nanotubes. Chem. Phys. Lett. 2003, 376, 154-158. [CrossRef]

36. Lin, D.; Xing, B. Adsorption of phenolic compounds by carbon nanotubes: Role of aromaticity and substitution of hydroxyl groups. Environ. Sci. Technol. 2008, 42, 7254-7259. [CrossRef]

37. Sitko, R.; Zawisza, B.; Malicka, E. Modification of carbon nanotubes for preconcentration, separation and determination of trace-metal ions. TrAC Trends Anal. Chem. 2012, 37, 22-31. [CrossRef]

38. Ray, P.Z.; Shipley, H.J. Inorganic nano-adsorbents for the removal of heavy metals and arsenic: A review. RSC Adv. 2015, 5, 29885-29907. [CrossRef]

39. Adeleye, A.S.; Conway, J.R.; Garner, K.; Huang, Y.; Su, Y.; Keller, A.A. Engineered nanomaterials for water treatment and remediation: Costs, benefits, and applicability. Chem. Eng. J. 2016, 286, 640-662. [CrossRef]

40. Adeleye, A.S.; Keller, A.A. Long-term colloidal stability and metal leaching of single wall carbon nanotubes: Effect of temperature and extracellular polymeric substances. Water Res. 2014, 49, 236-250. [CrossRef]

41. Li, Y.H.; Wang, S.; Wei, J.; Zhang, X.; Xu, C.; Luan, Z.; Wu, D.; Wei, B. Lead adsorption on carbon nanotubes. Chem. Phys. Lett. 2002, 357, 263-266. [CrossRef]

42. Gupta, V.K.; Agarwal, S.; Saleh, T.A. Chromium removal by combining the magnetic properties of iron oxide with adsorption properties of carbon nanotubes. Water Res. 2011, 45, 2207-2212. [CrossRef]

43. Di, Z.C.; Ding, J.; Peng, X.J.; Li, Y.H.; Luan, Z.K.; Liang, J. Chromium adsorption by aligned carbon nanotubes supported ceria nanoparticles. Chemosphere 2006, 62, 861-865. [CrossRef]

44. Peng, X.; Luan, Z.; Ding, J.; Di, Z.; Li, Y.; Tian, B. Ceria nanoparticles supported on carbon nanotubes for the removal of arsenate from water. Mater. Lett. 2005, 59, 399-403. [CrossRef]

45. Yu, F.; Wu, Y.; Li, X.; Ma, J. Kinetic and thermodynamic studies of toluene, ethylbenzene, and $\mathrm{m}$-xylene adsorption from aqueous solutions onto $\mathrm{KOH}$-activated multiwalled carbon nanotubes. J. Agric. Food Chem. 2012, 60, 12245-12253. [CrossRef]

46. Ren, X.; Chen, C.; Nagatsu, M.; Wang, X. Carbon nanotubes as adsorbents in environmental pollution management: A review. Chem. Eng. J. 2011, 170, 395-410. [CrossRef]

47. Rao, G.P.; Lu, C.; Su, F. Sorption of divalent metal ions from aqueous solution by carbon nanotubes: A review. Sep. Purif. Technol. 2007, 58, 224-231. [CrossRef]

48. Mubarak, N.M.; Sahu, J.N.; Abdullah, E.C.; Jayakumar, N.S. Removal of heavy metals from wastewater using carbon nanotubes. Sep. Purif. Rev. 2014, 43, 311-338. [CrossRef]

49. Kandah, M.I.; Meunier, J.L. Removal of nickel ions from water by multi-walled carbon nanotubes. J. Hazard. Mater. 2007, 146, 283-288. [CrossRef] [PubMed]

50. Pan, B.; Xing, B. Adsorption mechanisms of organic chemicals on carbon nanotubes. Environ. Sci. Technol. 2008, 42, 9005-9013. [CrossRef] [PubMed] 
51. Muñoz, J.; Gallego, M.; Valcárcel, M. Speciation of organometallic compounds in environmetal samples by gas chromatography after flow preconcentration on fullerenes and nanotubes. Anal. Chem. 2005, 77, 5389-5395. [CrossRef]

52. Long, R.Q.; Yang, R.T. Carbon nanotubes as superior sorbent for dioxin removal. J. Am. Chem. Soc. 2001, 123, 2058-2059. [CrossRef]

53. Cai, Y.Q.; Cai, Y.E.; Mou, S.F.; Lu, Y.Q. Multi-walled carbon nanotubes as a solid-phase extraction adsorbent for the determination of chlorophenols in environmental water samples. J. Chromatogr. A 2005, 1081, $245-247$. [CrossRef]

54. Zhou, Q.; Xiao, J.; Wang, W. Comparison of multiwalled carbon nanotubes and a conventional absorbent on the enrichment of sulfonylurea herbicides in water samples. Anal. Sci. 2007, 23, 189-192. [CrossRef]

55. Zhou, Q.; Xiao, J.; Wang, W.; Liu, G.; Shi, Q.; Wang, J. Determination of atrazine and simazine in environmental water samples using multiwalled carbon nanotubes as the adsorbents for preconcentration prior to high performance liquid chromatography with diode array detector. Talanta 2006, 68, 1309-1315. [CrossRef]

56. Zhou, Q.; Xiao, J.; Wang, W. Using multi-walled carbon nanotubes as solid phase extraction adsorbents to determine dichlorodiphenyltrichloroethane and its metabolites at trace level in water samples by high performance liquid chromatography with UV detection. J. Chromatogr. A 2006, 1125, 152-158. [CrossRef]

57. Chi, W.; Shi, H.; Shi, W.; Guo, Y.; Guo, T. 4-Nitrophenol surface molecularly imprinted polymers based on multiwalled carbon nanotubes for the elimination of paraoxon pollution. J. Hazard. Mater. 2012, 227-228, 243-249. [CrossRef] [PubMed]

58. Lu, C.; Chiu, H.; Bai, H. Comparisons of adsorbent cost for the removal of zinc (II) from aqueous solution by carbon nanotubes and activated carbon. J. Nanosci. Nanotechnol. 2007, 7, 1647-1652. [CrossRef] [PubMed]

59. Lu, C.; Chiu, H. Adsorption of zinc(II) from water with purified carbon nanotubes. Chem. Eng. Sci. 2006, 61, 1138-1145. [CrossRef]

60. Lu, C.; Chiu, H.; Liu, C. Removal of zinc(II) from aqueous solution by purified carbon nanotubes: Kinetics and equilibrium studies. Ind. Eng. Chem. Res. 2006, 45, 2850-2855. [CrossRef]

61. Chen, C.L.; Wang, X.K.; Nagatsu, M. Europium adsorption on multiwall carbon nanotube/iron oxide magnetic composite in the presence of polyacrylic acid. Environ. Sci. Technol. 2009, 43, 2362-2367. [CrossRef]

62. Zeng, Y.; Zhao, L.; Wu, W.; Lu, G.; Xu, F.; Tong, Y.; Liu, W.; Du, J. Enhanced adsorption of malachite green onto carbon nanotube/polyaniline composites. J. Appl. Polym. Sci. 2013, 127, 2475-2482. [CrossRef]

63. Zhu, H.Y.; Jiang, R.; Xiao, L.; Zeng, G.M. Preparation, characterization, adsorption kinetics and thermodynamics of novel magnetic chitosan enwrapping nanosized $\gamma$-Fe2O3 and multi-walled carbon nanotubes with enhanced adsorption properties for methyl orange. Bioresour. Technol. 2010, 101, 5063-5069. [CrossRef]

64. Maggini, L.; Raquez, J.M.; Marega, R.; Jensen Ahrens, J.; Pineux, F.; Meyer, F.; Dubois, P.; Bonifazi, D. Magnetic poly(vinylpyridine)-coated carbon nanotubes: An efficient supramolecular tool for wastewater purification. ChemSusChem 2013, 6, 367-373. [CrossRef]

65. Li, X.; Chen, S.; Quan, X.; Zhang, Y. Enhanced adsorption of PFOA and PFOS on multiwalled carbon nanotubes under electrochemical assistance. Environ. Sci. Technol. 2011, 45, 8498-8505. [CrossRef]

66. Ursino, C.; Castro-Muñoz, R.; Drioli, E.; Gzara, L.; Albeirutty, M.H.; Figoli, A. Progress of nanocomposite membranes for water treatment. Membranes 2018, 8, 18. [CrossRef]

67. Kurwadkar, S.; Hoang, T.V.; Malwade, K.; Kanel, S.R.; Harper, W.F.; Struckhoff, G. Application of carbon nanotubes for removal of emerging contaminants of concern in engineered water and wastewater treatment systems. Nanotechnol. Environ. Eng. 2019, 4, 12. [CrossRef]

68. Ahn, C.H.; Baek, Y.; Lee, C.; Kim, S.O.; Kim, S.; Lee, S.; Kim, S.-H.; Bae, S.S.; Park, J.; Yoon, J. Carbon nanotube-based membranes: fabrication and application to desalination. J. Ind. Eng. Chem. 2012, 18, 1551-1559.

69. Hinds, B.J.; Chopra, N.; Rantell, T.; Andrews, R.; Gavalas, V.; Bachas, L.G. Aligned multiwalled carbon nanotube membranes. Science 2004, 303, 62-65.

70. Mattia, D.; Lee, K.P.; Calabrò, F. Water permeation in carbon nanotube membranes. Curr. Opin. Chem. Eng. 2014, 4, 32-37. [CrossRef]

71. Lee, K.J.; Park, H.D. The most densified vertically-aligned carbon nanotube membranes and their normalized water permeability and high pressure durability. J. Memb. Sci. 2016, 501, 144-151. [CrossRef] 
72. Lee, B.; Baek, Y.; Lee, M.; Jeong, D.H.; Lee, H.H.; Yoon, J.; Kim, Y.H. A carbon nanotube wall membrane for water treatment. Nat. Commun. 2015, 6, 7109. [CrossRef]

73. Trivedi, S.; Alameh, K. Effect of vertically aligned carbon nanotube density on the water flux and salt rejection in desalination membranes. Springerplus 2016, 5, 1158. [CrossRef]

74. Jafari, A.; Mahvi, A.H.; Nasseri, S.; Rashidi, A.; Nabizadeh, R.; Rezaee, R. Ultrafiltration of natural organic matter from water by vertically aligned carbon nanotube membrane. J. Environ. Heal. Sci. Eng. 2015, 13, 51. [CrossRef]

75. Choi, J.H.; Jegal, J.; Kim, W.N. Fabrication and characterization of multi-walled carbon nanotubes/polymer blend membranes. J. Memb. Sci. 2006, 284, 406-415. [CrossRef]

76. Wu, H.; Tang, B.; Wu, P. Novel ultrafiltration membranes prepared from a multi-walled carbon nanotubes/polymer composite. J. Memb. Sci. 2010, 362, 374-383. [CrossRef]

77. Brunet, L.; Lyon, D.Y.; Zodrow, K.; Rouch, J.-C.; Caussat, B.; Serp, P.; Remigy, J.-C.; Wiesner, M.R.; Alvarez, P.J.J. Properties of Membranes Containing Semi-dispersed Carbon Nanotubes. Environ. Eng. Sci. 2008, 25, 565-576. [CrossRef]

78. Majeed, S.; Fierro, D.; Buhr, K.; Wind, J.; Du, B.; Boschetti-de-Fierro, A.; Abetz, V. Multi-walled carbon nanotubes (MWCNTs) mixed polyacrylonitrile (PAN) ultrafiltration membranes. J. Memb. Sci. 2012, 403-404, 101-109. [CrossRef]

79. Ahmed, F.; Santos, C.M.; Mangadlao, J.; Advincula, R.; Rodrigues, D.F. Antimicrobial PVK: SWNT nanocomposite coated membrane for water purification: Performance and toxicity testing. Water Res. 2013, 47, 3966-3975. [CrossRef]

80. Mehwish, N.; Kausar, A.; Siddiq, M. High-performance polyvinylidene fluoride/poly(styrene-butadiene-styrene)/ functionalized MWCNTs-SCN-Ag nanocomposite membranes. Iran. Polym. J. 2015, 24, 549-559. [CrossRef]

81. Shawky, H.A.; Chae, S.R.; Lin, S.; Wiesner, M.R. Synthesis and characterization of a carbon nanotube/polymer nanocomposite membrane for water treatment. Desalination 2011, 272, 46-50. [CrossRef]

82. Zhao, H.; Qiu, S.; Wu, L.; Zhang, L.; Chen, H.; Gao, C. Improving the performance of polyamide reverse osmosis membrane by incorporation of modified multi-walled carbon nanotubes. J. Memb. Sci. 2014, 450, 249-256. [CrossRef]

83. Zarrabi, H.; Yekavalangi, M.E.; Vatanpour, V.; Shockravi, A.; Safarpour, M. Improvement in desalination performance of thin film nanocomposite nanofiltration membrane using amine-functionalized multiwalled carbon nanotube. Desalination 2016, 394, 83-90. [CrossRef]

84. Lee, J.; Ye, Y.; Ward, A.J.; Zhou, C.; Chen, V.; Minett, A.I.; Lee, S.; Liu, Z.; Chae, S.R.; Shi, J. High flux and high selectivity carbon nanotube composite membranes for natural organic matter removal. Sep. Purif. Technol. 2016, 163, 109-119. [CrossRef]

85. Ho, K.C.; Teow, Y.H.; Ang, W.L.; Mohammad, A.W. Novel GO/OMWCNTs mixed-matrix membrane with enhanced antifouling property for palm oil mill effluent treatment. Sep. Purif. Technol. 2017, 177, 337-349. [CrossRef]

86. Liu, L.; Son, M.; Chakraborty, S.; Bhattacharjee, C.; Choi, H. Fabrication of ultra-thin polyelectrolyte/carbon nanotube membrane by spray-assisted layer-by-layer technique: Characterization and its anti-protein fouling properties for water treatment. Desalin. Water Treat. 2013, 51, 6194-6200. [CrossRef]

87. Ihsanullah. Carbon nanotube membranes for water purification: Developments, challenges, and prospects for the future. Sep. Purif. Technol. 2019, 209, 307-337. [CrossRef]

88. Zhang, L.; Shi, G.Z.; Qiu, S.; Cheng, L.H.; Chen, H.L. Preparation of high-flux thin film nanocomposite reverse osmosis membranes by incorporating functionalized multi-walled carbon nanotubes. Desalin. Water Treat. 2011, 34, 19-24. [CrossRef]

89. Kim, H.J.; Choi, K.; Baek, Y.; Kim, D.G.; Shim, J.; Yoon, J.; Lee, J.C. High-performance reverse osmosis CNT/polyamide nanocomposite membrane by controlled interfacial interactions. ACS Appl. Mater. Interfaces 2014, 6, 2819-2829. [CrossRef] [PubMed]

90. Peigney, A.; Laurent, C.; Flahaut, E.; Bacsa, R.R.; Rousset, A. Specific surface area of carbon nanotubes and bundles of carbon nanotubes. Carbon 2001, 39, 507-514. [CrossRef]

91. Di Paola, A.; García-López, E.; Marcì, G.; Palmisano, L. A survey of photocatalytic materials for environmental remediation. J. Hazard. Mater. 2012, 211-212, 3-29. [CrossRef]

92. Saleh, A.T. The Role of Carbon Nanotubes in Enhancement of Photocatalysis. In Syntheses and Applications of Carbon Nanotubes and Their Composites; InTech: London, UK, 2013. 
93. Yao, Y.; Li, G.; Ciston, S.; Lueptow, R.M.; Gray, K.A. Photoreactive TiO2/carbon nanotube composites: Synthesis and reactivity. Environ. Sci. Technol. 2008, 42, 4952-4957. [CrossRef]

94. Duong, T.T.; Nguyen, Q.D.; Hong, S.K.; Kim, D.; Yoon, S.G.; Pham, T.H. Enhanced photoelectrochemical activity of the TiO 2/ITO nanocomposites grown onto single-walled carbon nanotubes at a low temperature by nanocluster deposition. Adv. Mater. 2011, 23, 5557-5562. [CrossRef]

95. Martínez, C.; Canle L, M.; Fernández, M.I.; Santaballa, J.A.; Faria, J. Kinetics and mechanism of aqueous degradation of carbamazepine by heterogeneous photocatalysis using nanocrystalline $\mathrm{TiO} 2, \mathrm{ZnO}$ and multi-walled carbon nanotubes-anatase composites. Appl. Catal. B Environ. 2011, 102, 563-571. [CrossRef]

96. Silva, C.G.; Faria, J.L. Photocatalytic oxidation of benzene derivatives in aqueous suspensions: Synergic effect induced by the introduction of carbon nanotubes in a TiO2 matrix. Appl. Catal. B Environ. 2010, 101, 81-89. [CrossRef]

97. Li, Z.; Gao, B.; Chen, G.Z.; Mokaya, R.; Sotiropoulos, S.; Li Puma, G. Carbon nanotube/titanium dioxide (CNT/TiO2) core-shell nanocomposites with tailored shell thickness, CNT content and photocatalytic/photoelectrocatalytic properties. Appl. Catal. B Environ. 2011, 110, 50-57. [CrossRef]

98. Wang, H.; Wang, H.L.; Jiang, W.F.; Li, Z.Q. Photocatalytic degradation of 2,4-dinitrophenol (DNP) by multi-walled carbon nanotubes (MWCNTs)/TiO2 composite in aqueous solution under solar irradiation. Water Res. 2009, 43, 204-210. [CrossRef] [PubMed]

99. Zhang, L.L.; Xiong, Z.; Zhao, X.S. Pillaring chemically exfoliated graphene oxide with carbon nanotubes for photocatalytic degradation of dyes under visible light irradiation. ACS Nano 2010, 4, 7030-7036. [CrossRef]

100. Li, S.; Yu, X.; Zhang, G.; Ma, Y.; Yao, J.; Keita, B.; Louis, N.; Zhao, H. Green chemical decoration of multiwalled carbon nanotubes with polyoxometalate-encapsulated gold nanoparticles: Visible light photocatalytic activities. J. Mater. Chem. 2011, 21, 2282-2287. [CrossRef]

101. Yan, Y.; Sun, H.; Yao, P.; Kang, S.Z.; Mu, J. Effect of multi-walled carbon nanotubes loaded with Ag nanoparticles on the photocatalytic degradation of rhodamine B under visible light irradiation. Appl. Surf. Sci. 2011, 257, 3620-3626. [CrossRef]

102. Qu, J.; Cong, Q.; Luo, C.; Yuan, X. Adsorption and photocatalytic degradation of bisphenol A by low-cost carbon nanotubes synthesized using fallen leaves of poplar. RSC Adv. 2013, 3, 961-965. [CrossRef]

103. Garcia, J.; Gomes, H.T.; Serp, P.; Kalck, P.; Figueiredo, J.L.; Faria, J.L. Platinum catalysts supported on MWNT for catalytic wet air oxidation of nitrogen containing compounds. Catal. Today 2005, 102, 101-109. [CrossRef]

104. Gomes, H.T.; Samant, P.V.; Serp, P.; Kalck, P.; Figueiredo, J.L.; Faria, J.L. Carbon nanotubes and xerogels as supports of well-dispersed Pt catalysts for environmental applications. Appl. Catal. B Environ. 2004, 54, 175-182. [CrossRef]

105. Taboada, C.D.; Batista, J.; Pintar, A.; Levec, J. Preparation, characterization and catalytic properties of carbon nanofiber-supported Pt, Pd, Ru monometallic particles in aqueous-phase reactions. Appl. Catal. B Environ. 2009, 89, 375-382. [CrossRef]

106. Garcia, J.; Gomes, H.T.; Serp, P.; Kalck, P.; Figueiredo, J.L.; Faria, J.L. Carbon nanotube supported ruthenium catalysts for the treatment of high strength wastewater with aniline using wet air oxidation. Carbon 2006, 44, 2384-2391. [CrossRef]

107. Yang, S.; Zhu, W.; Li, X.; Wang, J.; Zhou, Y. Multi-walled carbon nanotubes (MWNTs) as an efficient catalyst for catalytic wet air oxidation of phenol. Catal. Commun. 2007, 8, 2059-2063. [CrossRef]

108. Yang, S.; Li, X.; Zhu, W.; Wang, J.; Descorme, C. Catalytic activity, stability and structure of multi-walled carbon nanotubes in the wet air oxidation of phenol. Carbon 2008, 46, 445-452. [CrossRef]

109. Mestl, G.; Maksimova, N.I.; Keller, N.; Roddatis, V.V.; Schlögl, R. Carbon Nanofilaments in Heterogeneous Catalysis: An Industrial Application for New Carbon Materials? Angew. Chemie Int. Ed. 2001, 40, 2066-2068. [CrossRef]

110. Kim, K.H.; Ihm, S.K. Heterogeneous catalytic wet air oxidation of refractory organic pollutants in industrial wastewaters: A review. J. Hazard. Mater. 2011, 186, 16-34. [CrossRef] [PubMed]

111. Sweetman, M.; May, S.; Mebberson, N.; Pendleton, P.; Vasilev, K.; Plush, S.; Hayball, J. Activated Carbon, Carbon Nanotubes and Graphene: Materials and Composites for Advanced Water Purification. C J. Carbon Res. 2017, 3, 18. [CrossRef]

112. Kang, S.; Pinault, M.; Pfefferle, L.D.; Elimelech, M. Single-walled carbon nanotubes exhibit strong antimicrobial activity. Langmuir 2007, 23, 8670-8673. [CrossRef] [PubMed] 
113. Tang, Y.J.; Ashcroft, J.M.; Chen, D.; Min, G.; Kim, C.H.; Murkhejee, B.; Larabell, C.; Keasling, J.D.; Chen, F.F. Charge-associated effects of fullerene derivatives on microbial structural integrity and central metabolism. Nano Lett. 2007, 7, 754-760. [CrossRef]

114. Kang, S.; Mauter, M.S.; Elimelech, M. Microbial cytotoxicity of carbon-based nanomaterials: Implications for river water and wastewater effluent. Environ. Sci. Technol. 2009, 43, 2648-2653. [CrossRef]

115. Brady-Estévez, A.S.; Kang, S.; Elimelech, M. A single-walled-carbon-nanotube filter for removal of viral and bacterial pathogens. Small 2008, 4, 481-484. [CrossRef]

116. Bui, N.; Meshot, E.R.; Kim, S.; Peña, J.; Gibson, P.W.; Wu, K.J.; Fornasiero, F. Ultrabreathable and Protective Membranes with Sub-5 nm Carbon Nanotube Pores. Adv. Mater. 2016, 28, 5871-5877. [CrossRef]

117. Baek, Y.; Kim, C.; Seo, D.K.; Kim, T.; Lee, J.S.; Kim, Y.H.; Ahn, K.H.; Bae, S.S.; Lee, S.C.; Lim, J.; et al. High performance and antifouling vertically aligned carbon nanotube membrane for water purification. J. Memb. Sci. 2014, 460, 171-177. [CrossRef]

118. Dong, X.; Yang, L. Dual functional nisin-multi-walled carbon nanotubes coated filters for bacterial capture and inactivation. J. Biol. Eng. 2015, 9, 20. [CrossRef] [PubMed]

119. Holt, J.K.; Park, H.G.; Wang, Y.; Stadermann, M.; Artyukhin, A.B.; Grigoropoulos, C.P.; Noy, A.; Bakajin, O. Fast mass transport through sub-2-nanometer carbon nanotubes. Science 2006, 312, 1034-1037. [CrossRef] [PubMed]

120. Sanip, S.M.; Ismail, A.F.; Goh, P.S.; Soga, T.; Tanemura, M.; Yasuhiko, H. Gas separation properties of functionalized carbon nanotubes mixed matrix membranes. Sep. Purif. Technol. 2011, 78, 208-213. [CrossRef]

121. Das, R.; Leo, B.F.; Murphy, F. The Toxic Truth About Carbon Nanotubes in Water Purification: A Perspective View. Nanoscale Res. Lett. 2018, 13, 183. [CrossRef] [PubMed]

122. Dumée, L.F.; Sears, K.; Schütz, J.; Finn, N.; Huynh, C.; Hawkins, S.; Duke, M.; Gray, S. Characterization and evaluation of carbon nanotube Bucky-Paper membranes for direct contact membrane distillation. J. Memb. Sci. 2010, 351, 36-43. [CrossRef]

123. Kar, S.; Bindal, R.C.; Tewari, P.K. Carbon nanotube membranes for desalination and water purification: Challenges and opportunities. Nano Today 2012, 7, 385-389. [CrossRef]

124. US7993524B2-Membranes with Embedded Nanotubes for Selective Permeability-Google Patents. Available online: https://patents.google.com/patent/US7993524B2/en (accessed on 23 July 2020).

125. Yang, H.Y.; Han, Z.J.; Yu, S.F.; Pey, K.L.; Ostrikov, K.; Karnik, R. Carbon nanotube membranes with ultrahigh specific adsorption capacity for water desalination and purification. Nat. Commun. 2013, 4, 2220. [CrossRef]

126. Yu, M.; Funke, H.H.; Falconer, J.L.; Noble, R.D. High density, vertically-aligned carbon nanotube membranes. Nano Lett. 2009, 9, 225-229. [CrossRef]

127. Gong, X.; Li, J.; Xu, K.; Wang, J.; Yang, H. A controllable molecular sieve for $\mathrm{Na}+$ and $\mathrm{K}+$ ions. J. Am. Chem. Soc. 2010, 132, 1873-1877. [CrossRef]

128. Majumder, M.; Zhan, X.; Andrews, R.; Hinds, B.J. Voltage gated carbon nanotube membranes. Langmuir 2007, 23, 8624-8631. [CrossRef]

129. Fornasiero, F.; Hyung, G.P.; Holt, J.K.; Stadermann, M.; Grigoropoulos, C.P.; Noy, A.; Bakajin, O. Ion exclusion by sub-2-nm carbon nanotube pores. Proc. Natl. Acad. Sci. USA. 2008, 105, 17250-17255. [CrossRef] [PubMed]

130. Son, M.; Choi, H.; Liu, L.; Celik, E.; Park, H.; Choi, H. Efficacy of carbon nanotube positioning in the polyethersulfone support layer on the performance of thin-film composite membrane for desalination. Chem. Eng. J. 2015, 266, 376-384. [CrossRef]

131. Pérez López, B.; Merkoçi, A. Improvement of the electrochemical detection of catechol by the use of a carbon nanotube based biosensor. Analyst 2009, 134, 60-64. [CrossRef] [PubMed]

132. Georgakilas, V.; Perman, J.A.; Tucek, J.; Zboril, R. Broad Family of Carbon Nanoallotropes: Classification, Chemistry, and Applications of Fullerenes, Carbon Dots, Nanotubes, Graphene, Nanodiamonds, and Combined Superstructures. Chem. Rev. 2015, 115, 4744-4822. [CrossRef]

133. Zhang, X.; Teng, Y.; Fu, Y.; Zhang, S.; Wang, T.; Wang, C.; Jin, L.; Zhang, W. Lectin-based electrochemical biosensor constructed by functionalized carbon nanotubes for the competitive assay of glycan expression on living cancer cells. Chem. Sci. 2011, 2, 2353-2360.

134. Miller, S.A.; Young, V.Y.; Martin, C.R. Electroosmotic flow in template-prepared carbon nanotube membranes. J. Am. Chem. Soc. 2001, 123, 12335-12342. [CrossRef]

135. Srivastava, A.; Srivastava, O.N.; Talapatra, S.; Vajtai, R.; Ajayan, P.M. Carbon nanotube filters. Nat. Mater. 2004, 3, 610-614. [CrossRef] 
136. Chatterjee, A.N.; Cannon, D.M.; Gatimu, E.N.; Sweedler, J.V.; Aluru, N.R.; Bohn, P.W. Modeling and simulation of ionic currents in three-dimensional microfluidic devices with nanofluidic interconnects. $J$. Nanoparticle Res. 2005, 7, 507-516. [CrossRef]

137. Zou, Y.; Xiang, C.; Yang, L.; Sun, L.X.; Xu, F.; Cao, Z. A mediatorless microbial fuel cell using polypyrrole coated carbon nanotubes composite as anode material. Int. J. Hydrogen Energy 2008, 33, 4856-4862. [CrossRef]

138. Qiao, Y.; Li, C.M.; Bao, S.J.; Bao, Q.L. Carbon nanotube/polyaniline composite as anode material for microbial fuel cells. J. Power Sources 2007, 170, 79-84. [CrossRef]

139. Mink, J.E.; Rojas, J.P.; Logan, B.E.; Hussain, M.M. Vertically Grown Multiwalled Carbon Nanotube Anode and Nickel Silicide Integrated High Performance Microsized (1.25 $\mu \mathrm{L})$ Microbial Fuel Cell. Nano Lett. 2012, 12, 791-795. [CrossRef] [PubMed]

140. Xie, X.; Hu, L.; Pasta, M.; Wells, G.F.; Kong, D.; Criddle, C.S.; Cui, Y. Three-dimensional carbon nanotube-textile anode for high-performance microbial fuel cells. Nano Lett. 2011, 11, 291-296. [CrossRef] [PubMed]

141. Liu, X.W.; Sun, X.F.; Huang, Y.X.; Sheng, G.P.; Wang, S.G.; Yu, H.Q. Carbon nanotube/chitosan nanocomposite as a biocompatible biocathode material to enhance the electricity generation of a microbial fuel cell. Energy Environ. Sci. 2011, 4, 1422-1427. [CrossRef]

142. Chen, Y.; Lv, Z.; Xu, J.; Peng, D.; Liu, Y.; Chen, J.; Sun, X.; Feng, C.; Wei, C. Stainless steel mesh coated with $\mathrm{MnO} 2 /$ carbon nanotube and polymethylphenyl siloxane as low-cost and high-performance microbial fuel cell cathode materials. J. Power Sources 2012, 201, 136-141. [CrossRef]

143. Zhang, Y.; Hu, Y.; Li, S.; Sun, J.; Hou, B. Manganese dioxide-coated carbon nanotubes as an improved cathodic catalyst for oxygen reduction in a microbial fuel cell. J. Power Sources 2011, 196, 9284-9289. [CrossRef]

144. Lam, C.W.; James, J.T.; McCluskey, R.; Arepalli, S.; Hunter, R.L. A review of carbon nanotube toxicity and assessment of potential occupational and environmental health risks. Crit. Rev. Toxicol. 2006, 36, 189-217. [CrossRef]

145. Francis, A.P.; Devasena, T. Toxicity of carbon nanotubes: A review. Toxicol. Ind. Health 2018, 34, $200-210$. [CrossRef]

146. Jafar, A.; Alshatti, Y.; Ahmad, A. Carbon nanotube toxicity: The smallest biggest debate in medical care. Cogent Med. 2016, 3. [CrossRef]

147. Mehra, N.K.; Jain, A.K.; Lodhi, N.; Raj, R.; Dubey, V.; Mishra, D.; Nahar, M.; Jain, N.K. Challenges in the Use of Carbon Nanotubes for Biomedical Applications. Crit. Rev. Ther. Drug Carr. Syst. 2008, 25, 169-206. [CrossRef]

(C) 2020 by the authors. Licensee MDPI, Basel, Switzerland. This article is an open access article distributed under the terms and conditions of the Creative Commons Attribution (CC BY) license (http://creativecommons.org/licenses/by/4.0/). 